La Revue

des Droits

de l'Homme

\section{La Revue des droits de l'homme}

Revue du Centre de recherches et d'études sur les droits fondamentaux

$4 \mid 2013$

Revue des droits de l'homme - $\mathrm{N}^{\circ} 4$

\title{
Human Dignity in the Discourse of the Slovenian Constitutional Court
}

Analysis of the Constitutional Court Decision U-I-109/10

Matija Žgur

\section{(2) OpenEdition}

\section{Journals}

Electronic version

URL: http://journals.openedition.org/revdh/407

DOI: $10.4000 /$ revdh.407

ISSN: 2264-119X

Publisher

Centre de recherches et d'études sur les droits fondamentaux

Electronic reference

Matija Žgur, " Human Dignity in the Discourse of the Slovenian Constitutional Court », La Revue des droits de l'homme [Online], 4 | 2013, Online since 01 December 2013, connection on 10 December 2020. URL : http://journals.openedition.org/revdh/407 ; DOI : https://doi.org/10.4000/revdh.407

This text was automatically generated on 10 December 2020 .

Tous droits réservés 


\title{
Human Dignity in the Discourse of the Slovenian Constitutional Court
}

\author{
Analysis of the Constitutional Court Decision U-I-109/10
}

Matija Žgur

I would like to thank Matej Avbelj, Tilen Štajnpihler and Saša Zagorc for their helpful comments on earlier drafts of this paper.

\section{Introduction}

1 The concept of human dignity assumes many forms in constitutional discourse. It is often referred to as being the philosophical basis of human rights ${ }^{1}$. Some modern constitutions declare it as their supreme principle and/or fundamental value ${ }^{2}$. It is also not uncommon that human dignity is understood and protected either as a constitutional right on its own or by way of other constitutional rights ${ }^{3}$.

Though its legal status is almost universally accepted as of utmost importance, there is little agreement on its content - both in theory and in practice. Dignity is an essentially contested concept ${ }^{4}$. Implications of this lack of definitional consensus are particularly evident in constitutional adjudication with courts invoking the notion of human dignity in their decision-making. National constitutional courts or other courts of last instance, in their capacity as the highest guardians of constitutional (human) rights ${ }^{5}$, are often the ones responsible for determining the concept's content and scope of application. This view of dignity as the basis of human rights and/or as the fundamental constitutional principle prevails in many new democracies, such as, and including, Slovenia ${ }^{6}$.

3 This article explores how the concept of human dignity is perceived and applied in the case-law of the Slovenian Constitutional Court (hereinafter: the Constitutional Court or the Court). It focuses on the Court's recent case in which human dignity was applied as a litmus test of constitutionality of an authoritative act. The Court held that a municipal ordinance naming a street after Josip Broz Tito, the president of the former 
Socialist Federal Republic of Yugoslavia (SFRY), was unconstitutional since the symbolism attached to the name Tito can objectively be understood as recognition and glorification of the former non-democratic regime he led. According to the Court, such action on the part of public authorities is contrary to the principle of respect for human dignity whose foundation lies in Article 1 of the Constitution that establishes the Republic of Slovenia as a democratic republic.

This decision is of particular interest for two reasons: one, it marks the first time that the concept of human dignity was invoked as an independent principle and the main argument in the Court's decision-making process; two, with this decision, the Court established that human dignity is an essential element of the principle of democracy.

5 The article proceeds in the following way: first, a detailed presentation of the case facts and of the Court's reasoning is given. A brief excursion offering an insight into the German Constitutional Court's understanding of human dignity serves to demonstrate the influences on the Slovenian Constitutional Court's approach to this issue. After that, the Court's discourse on human dignity leading up to the Tito Street case is presented. Finally, a two-fold criticism of the Court's decision is offered.

\section{Facts of the case}

6 The case was brought before the Court by a group of four petitioners, claiming that their right to personal dignity ${ }^{7}$ had been violated by the naming of a street after Josip Broz Tito, who, in their opinion, personified the communist regime of the former SFRY. In addition, they asserted violation of Article 63 of the Constitution ${ }^{8}$. According to the petitioners, this provision protects constitutionally guaranteed categories of equality, human dignity and a democratic state governed by the rule of law: values that are in stark contradiction to those fostered in the former totalitarian regime.

The petitioners argued that Josip Broz Tito personally supervised and dictated the development of the communist regime ${ }^{9}$. They claimed that, historically looking, he was a negative persona, an anti-democrat and a dictator and that naming the street after him therefore entails a particular kind of incitement to hatred and violence. The contested ordinance in consequence once again humiliates those who have been unjustifiably marginalized in the former regime due to their political convictions.

The petitioners also called attention to several domestic and international documents which declare the non-democratic nature of totalitarian regimes of the latter part of the $20^{\text {th }}$ century ${ }^{10}$, thus adding weight to the claimed incompatibility between those regimes and the values fostered by contemporary democratic regimes.

The opposing party (the City Municipality of Ljubljana) primarily contested the petitioners' legal interest (i.e. standing) to initiate proceedings for the review of constitutionality of the ordinance. It argued that only individuals with permanent or temporary residence in the area to which the changes (i.e. the new naming) relate demonstrate such legal interest. Secondly, they objected to the alleged unconstitutionality of the ordinance. The municipality argued that the disputed street was named after Tito in recognition of his historic importance for the Slovenian people and their state. As commander-in-chief of the Partisan army he led the 1945 liberation of present-day Slovenia from fascist occupation. Numerous commendations that Josip Broz Tito received from foreign states, as well as the fact that many cities around the 
world named public facilities after him testify to his great historical role. In conclusion, they added that although discussions on naming streets can be a matter of democratic dialogue, the final decision on the issue is the democratic right of the majority in the municipal council.

\section{Holding}

10 Based on the arguments set forth by the parties, the Court was faced with having to address two separate yet related problems. First, they had to decide whether the petitioners demonstrated legal interest in the initiation of the procedure for the review of constitutionality of the ordinance ${ }^{11}$. Second, they had to determine whether Article 2 of the ordinance, determining the name of the new street, was inconsistent with the principle of respect for human dignity, i.e. whether the naming of the street after Josip Broz Tito violated the petitioners' constitutional rights.

11 Hereupon I focus on the second problem, i.e. the purported violation of the human dignity principle. With regard to the matter of legal interest, the Court first established that the naming of streets has a direct effect in relation to all public and private legal subjects in their daily lives and business activities. Second, claiming that the case at hand raised questions concerning human dignity and thus matters of the greatest importance for democratic rule ${ }^{12}$, the Court ruled that one of the petitioners, who had formally been recognized the status of a former political prisoner, did demonstrate legal interest, since rehabilitation after human rights violations that occurred in the totalitarian regime was an essential element of that petitioner's legal status ${ }^{13}$. With that, the Court found no reason to rule on the legal interest of other petitioners and proceeded to decide the case on merits.

\section{Violation of human dignity}

12 The Court initially argued that «[r]espect for human dignity is the legal-ethical foundation of contemporary states based on the concept of constitutional democracy, i.e. on the presumption that authority must be restricted by certain fundamental rights and freedoms humans are entitled to due to their inherent worth ${ }^{14}$. "With time, most prominently after World War II, the principle of respect for human dignity had come to be widely recognized as "a special universal principle » within the most important international human rights documents ${ }^{15}$, as well as «the fundamental constitutional principle in the constitutions of new democracies, which, by codifying human rights, placed the individual at the centre of the constitutional order ${ }^{16}$ ». The Republic of Slovenia is among those new democracies who have embraced this view of human dignity. Its founding (independence) documents convey the country's commitment to the protection of fundamental human rights ${ }^{17}$. It is on the basis of these documents that the Court developed the understanding that " human dignity is the fundamental value which permeates the entire legal order ${ }^{18}$ " and for that reason objectively influences all acts of public authorities. Substantively, it « entails the presumption that every human being has equal and absolute inner worth because he or she is a human being. Respect for human dignity therefore entails the protection of the inherent worth of the individual against unjustified interferences by and requirements of the state and society ${ }^{19}$." As such, i.e. as the fundamental value of the constitutional order, human 
dignity finds "normative expression in numerous provisions of the Constitution", above all in human rights provisions which protect different aspects of man's dignity ${ }^{20}$. This goes to show, argued the Court, that human dignity is the origin of human rights and a precondition for respect of other human rights.

Later on, in a key part of the decision, the Court proclaimed that respect for human dignity is a "special constitutional principle » and as such is « directly substantiated in Article 1 of the Constitution, which determines that Slovenia is a democratic republic ${ }^{21}$. Democracy, further argued the Court, is not merely a formal category - it is not sufficient that laws and other regulations are adopted in accordance with the rule of the majority. As a substantive category, the principle of democracy « defines the Republic of Slovenia as a constitutional democracy, thus as a state in which the acts of authorities are legally limited by constitutional principles and human rights and fundamental freedoms, precisely because individuals and their dignity are at the centre of its existence and functioning ${ }^{22}$. On that basis the Court concluded that the opposing party was wrong in arguing that the naming of the street is the right of the democratically elected majority in the municipal council: the principle of democracy « imposes a duty on all authorities - first of all on those that issue general legal acts to respect the boundaries which proceed from the constitutional order whose central principle is precisely the principle of respect for human dignity, when exercising their constitutional and statutory powers ${ }^{23}$. $\gg$ However, the Court acknowledged that due to the "substantive openness ${ }^{24}$ » of the principle of human dignity, the precise limits on what public authorities may do, cannot be specified in advance but are rather developed by the Court's case-law on a case-to-case basis.

Therefore, in the case at hand, the Court had to determine whether the decision of the municipal council to name a street after Tito was unconstitutional because the symbolic dimension of this act violated the petitioner's dignity. The Court declared that " a regulation or other act of the authorities which has a symbolic significance is unconstitutional in cases in which such symbol, through the power of the authority, expresses values which are incompatible with fundamental constitutional values, such as human dignity, freedom, democracy, and the rule of law ${ }^{25}$.» Moreover, the Court also emphasised that since authorities must always act in the public interest and because « expressing values that are contrary to the fundamental constitutional values cannot be in the public interest, the review of the constitutionality of the acts of authorities is not subject to the principle of proportionality (i.e. weighing between the public interest and the affected constitutional values), but such acts are in and of themselves unconstitutional ${ }^{26}$. »

It follows that the Court had to establish whether the values conveyed by the act i.e. the municipal ordinance were contrary to those proclaimed and protected by the constitutional order. The Court argued that the symbolic dimension of Tito Street « is inseparably connected with the symbolic significance of the name Josip Broz Tito, Marshal of Yugoslavia and later President for life of the SFRY ${ }^{27}$. " Unlike the opposing party, which argued that it named the street after Tito in recognition of his acts that enabled Slovenia's liberation from fascist occupation, the Court observed that despite of these facts, Tito was also a symbol of « the post-war totalitarian regime, which was marked by extensive and gross violations of human rights and fundamental freedoms ${ }^{28}$ [...] » Since the symbolism that Tito's name emits cannot be divided in such a way that significance of only one part of the actions attributed to him (or the regime he 
symbolizes) could be considered, the Court declared that naming a street after Tito « can be understood as support not only for him as a historical figure or his individual actions, but also as support for the entire historical period of his rule and for his rule as such $^{29}$. " What the authority's objective was with the naming is not important: what is important is that the naming, i.e. the challenged ordinance «must objectively be understood as a form of recognition conferred on the former undemocratic regime ${ }^{30}$. " Thereafter, the Court reiterated that authoritative expressions of recognition of the totalitarian regimes «[are] contrary to promoting respect for human dignity, human rights and fundamental freedoms, and other values which contemporary European constitutional democracies share ${ }^{31}$."

On the basis of the reasons stated above, the Court decided that any such new naming of a street by which the communist totalitarian regime is glorified, is unconstitutional since it contradicts the principle of respect for human dignity residing in Article 1 of the Constitution and consequently ruled that the disputed ordinance be annulled.

\section{Analysis: the Court's discourse on human dignity}

17 In the following two sections of the article the analysis and critique of the Court's decision is presented. In order to shed some light on the doctrinal origins and influences of the Court's understanding of human dignity, first a very brief and general account of the German Constitutional Court's (Bundesverfassungsgericht; hereinafter BVerfG) approach to the adjudication of human dignity is given. Later, by looking at some of its earlier decisions, the Slovenian Constitutional Court's use of the principle of human dignity leading up to the Tito Street case is presented. Finally, a two-fold criticism of the latter decision is provided.

\section{Human dignity adjudication in Germany}

It is reasonable to claim that Germany is the cradle of the prevalent modern (Western) philosophical and legal conceptions of human dignity ${ }^{32}$. Both are inextricably linked to Immanuel Kant's contribution to the understanding of the concept ${ }^{33}$. His view of dignity as an inherent, unconditional worth of men informs the perception of dignity in the German Basic Law (Grundgesetz) and the practice of the BVerfG. Rosen argues that " [o]fficially, the fundamental idea motivating the use of dignity in the Grundgesetz » is the understanding of "dignity as intrinsic value ${ }^{34}$.» As to its application, Walter demonstrates the various characterisations of the concept in the BVerfG's case-law: the Court has declared human dignity as being, above all, «the highest value of the Basic Law, informing the substance and spirit of the entire document ${ }^{35}$ », as well as "the centre of the scheme of constitutional values ${ }^{36}$ " and, finally, as the "fundamental constitutional principle dominating all parts of the constitution ${ }^{37}$. »

From the language of the constitution's Dignity clause and from the Constitutional Court's characterisations, we may observe some of the characteristics of the German constitutional conception of dignity ${ }^{38}$. Dignity is perceived as a universal characteristic of men, an objective feature, one that « requires attribution of rights to the individual which enable him or her to defend his or her design of life ${ }^{39}$. " From its position in the constitutional text, it is seen as a sort of a Grundnorm of the constitutional system, a norm that is, on the one hand, the source of all constitutional rights, and, on the other 
hand, the source of limitations and (positive) obligations for State organs; moreover, it serves as the fundamental value of the entire constitutional system and the principal interpretive tool for the interpretation of the Basic Law ${ }^{40}$.

One further alleged characteristic of the principle is, however, disputable. It has been argued that the principle of human dignity has absolute effect ${ }^{41}$ : namely, "that any encroachment upon human dignity means a violation ${ }^{42} »$ and that $«[t]$ he principle of proportionality does not come into play as long as an intrusion upon human dignity has been established ${ }^{43}$. " However, Rosen's analysis of the BVerfG's case-law uncovers an important shift that often occurs in the Court's decision-making. He shows that although « the fundamental idea motivating the use of dignity in the Grundgeset $z^{44}$ » is the idea of dignity as intrinsic value, "the German courts have often operated on the assumption that violations of dignity involve treatment that is in some way demeaning or degrading ${ }^{45}$ ». But as the following passage from the Court's Abhörurteil case shows, not any violation of one's dignity will amount to an unconstitutional treatment. It that case, the BVerfG argued:

« Human beings are frequently objects - not just of circumstances and of social developments, but also of the law, insofar as they must obey it without regard to their own interests. This is not sufficient for a violation of human dignity. It must also be the case that they are subjected to treatment that fundamentally calls into question their quality as subjects, or that treatment in a particular case contains arbitrary contempt for the dignity of the human being. Thus the treatment of human beings by public authority charged with executing the law, if it is to affront human dignity, must be an expression of contempt for the value that the human being has in virtue of being a person; it must, in this sense, be 'disrespectful treatment ${ }^{346}$."

21 From this short and inevitably superficial overview we may nevertheless deduce two important conclusions: First, that the language both the German and the Slovenian constitutional courts apply in the human dignity adjudication is highly alike. This leads to the conclusion that both courts rely on the same underlying conception of human dignity, one based in Kant's moral philosophy. Second, that the same shift in the underlying conception that Rosen noticed when it comes to German adjudication of dignity, seems to be present in the Tito Street case as well. The German Constitutional Court's Abhörurteil case reasoning raises an important question: whether the act of naming a street after a person, whose name may in some people invoke certain displeasing feelings, can truly amount to such an encroachment of one's dignity that it be seen as contemptful of the very core of one's worth, offending the very essence of an individual, and therefore also needed to be declared unconstitutional.

\section{The Court's discourse on human dignity prior to the Tito Street case}

Highlighting several key decisions, I hereafter present the application of the principle of human dignity established by the Slovenian Constitutional Court in its case-law leading up to the Tito Street decision.

The principle of human dignity features prominently in the Slovenian constitutional order and in the case-law of the Constitutional Court. The Preamble to the Constitution invokes reference to the Basic Constitutional Charter on the Sovereignty and Independence of the Republic of Slovenia, the document establishing Slovenia as an independent nation ${ }^{47}$. The Charter, inter alia, declares that the SFRY did not function as 
a state governed by law, that gross violations of human rights occurred within it and that the Republic of Slovenia will guarantee the protection of human rights and fundamental freedoms to all persons in the territory of the Republic. Additionally, the Preamble makes reference to fundamental rights and freedoms as one of the foundations of Slovenian constitutionality. Based on that fact, the Constitutional Court had in the past declared that the Preamble serves as a tool for the interpretation and axiological evaluation of the normative elements of the Constitution ${ }^{48}$. The Court had also previously made reference to the principle of dignity in connection to Article 1 of the Constitution, arguing that [ $[\mathrm{t}]$ he essence of the constitutional provision dealing with the separation of powers is [...] in its fundamental function of protection of individual's freedom and dignity in relation to the government ${ }^{49}$."

Most of the Court's case-law on human dignity, however, has been centred on Article 34 of the Constitution which protects the right to personal dignity and security ${ }^{50}$ i.e. on an article of the Constitution protecting human dignity as a specific right and not as a principle. Within the framework of this article, the Court made use of the notion of human dignity to decide various types of cases. For instance, the Court declared that prevention of performance of work to an employee is an encroachment on his rights protected under Article 34: «The possibility of professional and personal development, including achieving and developing status, position and reputation in the working and living surroundings, together with the undisputed importance of existential security, are indivisible elements that define the dignity and individuality of any individual ${ }^{51}$. " In another case, the Court decided that taking away all of a convicted person's financial assets for enforcing a civil claim against him would violate that individual's right to personal dignity as well as his right to social security ${ }^{52}$. Moreover, the right to personal dignity had also been associated with the right to privacy ${ }^{53}$, right to honour and good reputation $^{54}$, and other constitutional rights and principles.

25 A number of the Court's decisions directly address the issue of human dignity violations under the previous regime. In the early 1990's, directly following the independence, the Court issued several decisions in which it elaborated its position with regard to the former political system. In the aforementioned case U-I-158/94, the Court stated that

«the former Yugoslav system of constitution and government institutions [...] did not put in the first place human rights and did not define clear legal restrictions applying to the government authorities and their violence. Thus, it made possible arbitrary government, and its constitution was not a legal instrument in the full sense as understood by modern European civilization. »

In contrast, the most important direct objective of the new Constitution is «the protection of fundamental human rights and freedoms of every person here and now $^{55}$.»

Elsewhere, the Court argued that those living in the former communist regime were exposed to permanent and systematic violations of human rights and fundamental freedoms and were deprived of enjoying such rights as freedom of expression, right of political association, right of free enterprise etc. ${ }^{56}$ The Court also established that after the end of World War II, the authorities «carried out mass executions of former military and current political opponents, legally unacceptable trials followed by death penalties, illegal seizure of property, obstruction and liquidation of political parties in 
violation of its own legal system etc., thus making the injured parties afraid, with good reason, for their lives in case of residing in such a country ${ }^{57}$. "

This inquiry into the Court's decisions dealing with dignity enables us to make a few important observations. First, the Court views human rights as one of the pillars of Slovenian constitutionality and has established that the Preamble, which articulates this commitment, is an important tool of constitutional interpretation and axiological evaluation. Second, the Court had, prior to the Tito Street case, already invoked a connection between the principle of human dignity and Article 1 of the Constitution, but it did so by arguing that the principle of separation of powers is designed to, inter alia, protect individuals' dignity (as a right) and not, as it did in the Tito Street decision, by introducing the principle of human dignity as an essential element of democratic rule. Third, human dignity has served the Court as a basis for deliberation in a variety of cases, but always either in connection to some other right or principle or in the form of a specific constitutional provision protecting some aspect of the broader principle. Finally, in a series of decisions from the early 1990's, the Court positioned itself strongly in opposition to the previous socialist regime, articulating the legal, political and axiological discontinuity from the former system. These characteristics therefore represent the Courts axiological and legal premises with regard to human dignity adjudication and serve to elucidate the Court's reasoning in the Tito Street decision.

\section{A two-fold criticism of the decision}

In the final part of this paper I focus on presenting several instances in the Court's reasoning that I find disputable. My critique of the decision is in two parts. First, I discuss two instances in which the Court attempted to present its particular view of dignity as "objective ». Finally, I show that two main characterisations of the human dignity's role in the constitutional system, which represent the core of the Court's reasoning, conflict with each other and cause the decision to lack internal coherence.

\section{First criticism: Objectification}

30 McCrudden notes that jurisdictions differ on "whether dignity is to be interpreted from the point of view of the victim or 'objectively ${ }^{158}$.» Both approaches pose certain problems:

« On the one hand, for the court to say that the appropriate approach is to adopt a particular individual's own judgment on what seems to breach his or her dignity is to risk putting in place an unmanageable and unworkable standard. On the other hand, adopting an entirely court-centred view of what constitutes a breach of dignity seems patronizing ${ }^{59}$.»

31 McCrudden then shows that some courts adopt a mixed subjective-objective approach. This approach, according to the Canadian Court of Appeal for Ontario, «requires a court to consider the individual's or group's traits, history, and circumstances in order to evaluate whether a reasonable person, in circumstances similar to the claimant, would find that the impugned law differentiates in a manner which demeans his or her dignity ${ }^{60}$. " But as McCrudden warns, in my opinion rightly, "this hardly seems a particularly stable approach, and in practice has sometimes led to courts adopting what seems like an almost entirely objective approach, where the court effectively imposes its own views ${ }^{61}[. .]$.$» Therefore, an objective approach to the interpretation of human$ 
dignity, regardless of the reasons for its use or the manner in which it is presented, allows, above all, for the introduction of judicial voluntarism and is therefore an illsuited approach to dignity adjudication ${ }^{62}$.

There are two important instances in the Tito Street decision in which we may observe that the Court attempted to vest its opinion in the cloak of objectivity. In the first instance, the Court claimed that as the fundamental value which permeates the entire legal order, dignity " has an objective significance in the functioning of authority not only in individual proceedings but also when adopting regulations ${ }^{63}$. " Public authorities are thus bound to protect the inherent worth of the individual in their activities. Now, if this directive were to serve as the major premise in the decisionmaking of public officials (even if as a 'meta' major premise), the principle of legal foreseeability requires that the content of the obligations of public authorities be, to the greatest possible extent, determined in advance, so to allow for their adoption in the daily decision-making of officials. However, if we again observe the Court's acknowledgment in Paragraph 11 of the decision, that « a firm and complete a priori definition of human dignity is not possible » and that furthermore «boundaries of the admissible conduct of state authorities are developed through the decisions of the courts and the Constitutional Court, which take into consideration the specific circumstances of individual cases ", we see that an ex ante determination of what actions of authoritative bodies are consistent with the principle of respect for human dignity is nearly impossible ${ }^{64}$. Consequently, foreseeability of what is legally permissible is greatly diminished if not entirely eliminated.

The second instance in which we can observe the Court's attempt to project an image of objectivity is even more problematic for the perception of the final decision's argumentative quality. In deciding whether the naming of the street after Tito was consistent with the principle of respect for human dignity, the Court emphasised that its goal in doing that was neither to review « the personality and individual actions of Josip Broz Tito » nor to conduct a « historical review of facts and circumstances ${ }^{65}$. » As the guardians of the Constitution and the values on which it is based, their sole task was to " establish constitutionally important circumstances taking into consideration the constitutional order in force and on such basis decide on the constitutionality of the challenged regulation ${ }^{66}$. » But arguably, contrary to the declared, the Court had in fact undertaken an evaluation of the historical facts as well as of Tito's personality and his actions. This much is evident from Paragraphs 15 and 16 of the Court's decision ${ }^{67}$. This discrepancy in the Court's actions was noted among commentators of the decision. On the one hand, Šturm argues that it is an imminent task of constitutional review when there is a meaningful connection with the subject of review - to take a position with regard to the historically attested violations of human rights and fundamental freedoms which have occurred in the former totalitarian system ${ }^{68}$. Furthermore, the author claims that constitutional adjudication plays an indispensable role in the process of transforming post-totalitarian social order into a system of constitutional democracy with a free democratic society ${ }^{69}$. Avbelj, from a different point of view and criticising the Court's methodological approach, reaches a similar conclusion. He argues:

"I wonder how the Constitutional Court can determine that the name Josip Broz Tito is axiologically incompatible with the current Constitution without first assessing his historical role. How can someone determine that the meaning of a symbol is 'objectively' incompatible with the new constitutional order, without 
having previously adopted an appropriate interpretation of the overall historical characteristics of the person whose name today cannot be used even for symbolical purposes? This, from the epistemological-hermeneutical point of view, is simply impossible. The assessment that a name is symbolically abject simply must be based on an interpretive assessment of the historical actions of that person and the quality of the state, head of which that person was. If that assessment is objective, as it is claimed, that could only mean that it is widely intersubjectively accepted. In the social world there is no 'neutral' depersonalized objectivity in the sense of natural sciences ${ }^{70}$. " only on the constitutional assessment and not on the interpretation and evaluation of facts and circumstances of that historical period is not only wrong from the point of view of constitutional argumentation but also epistemologically-hermeneutically unfeasible. "If it were to follow it, the Constitutional Court would not be able to issue this decision for it would lack one of the two premises needed for the final [...] syllogistic conclusion ${ }^{71}$.» While both seem to agree that the Court has every right, and indeed, when circumstances call for it, a duty to engage in an (axiological) evaluation of historical facts, Avbelj's analysis demonstrates that an attempt to conceal such an assessment is not just unnecessary, but rather methodologically inappropriate, even all together inappropriate.

\section{Second criticism: Lack of coherence}

Coherence of legal reasoning is "an elementary postulate of rationality " being one of the fundamental characteristics of contemporary law ${ }^{73}$. In the context of judicial reasoning, especially at the level of constitutional adjudication, its importance is even more accentuated. As Bertea notes, though there is « wide agreement [...] over the characterisation of coherence in the negative as lack of inconsistencies ${ }^{74}$ ", as to the positive characterisation, there is much more controversy. Nevertheless, the minimum condition seems to be that propositions be logically consistent ${ }^{75}$. It is claimed that additionally, coherence should at least entail « comprehensiveness and completeness (at least to some degree), support (of varying scope and force), and cross-connection and mutual justification between the parts of a whole ${ }^{76}$.» Aware of the limitations of arguing from the argument of coherence ${ }^{77}$, I nevertheless wish to claim that the Court's reasoning in the Tito Street case lacks internal coherence. I take this to mean the lack of semantic consistency in the Court's characterization of the concept of human dignity when used as the central argument upon which it based its decision.

Let us observe the disputed characterisations. In Paragraph 4, the Court determines that « human dignity [is] the fundamental value and legal starting point of Slovenian democracy. » Later on, in Paragraph 6, it seems to further develop this interpretation, saying that «[r]espect for human dignity is the legal-ethical foundation of contemporary states based on the concept of constitutional democracy ». In these two passages the Court establishes human dignity as a meta-constitutional principle upon which the entire constitutional system rests. Let us name this conception A. However, in Paragraph 10 the following claim is made: «As a special constitutional principle, the principle for respect for human dignity is directly substantiated in Article 1 of the Constitution, which determines that Slovenia is a democratic republic. » Here, human dignity is perceived as (just) an element of the principle of democracy. Let us call this conception B. Immediately we notice that conception A (human dignity as the meta- 
constitutional principle) is substantially different from conception B (human dignity as an element of the principle of democracy). While in Paragraphs 4 and 6 the Court views dignity as the supreme legal and axiological principle of the legal and political system, in Paragraph 10 it reduces it to a principle that is derivative from the principle of democracy. Furthermore, in the same Paragraph 10, the Court offers another characterisation of the principle, one that again seems in line with conception A. It states: «the principle of democracy substantively defines the Republic of Slovenia as a constitutional democracy, thus as a state in which the acts of authorities are legally limited by constitutional principles and human rights and fundamental freedoms, precisely because individuals and their dignity are at the centre of its existence and functioning. » Clearly, conceptions A and B are at odds with each other. If dignity is the starting point of Slovenian democracy which is substantively characterised as a constitutional democracy ${ }^{78}$ - thus being axiologically and normatively superior to the principle of democracy, we find that conception B is inconsistent with conception A: dignity cannot derive from the principle of democracy if it is superior to it. This discrepancy is not to be taken too lightly since we recall that it was conception B that was the interpretation of the principle of dignity on which the Court based its ruling on. If, for the argument's sake, we take it that this latter interpretation of the principle is the one the Court intended to enforce, we are left with the problem of determining what precise legal power, if any, the Court intended to confer to conception A. In this case, it seems that human dignity is can't be perceived as the highest and fundamental value of the constitutional system. If, on the other hand, it is the view that human dignity serves as the supreme principle of the constitutional system that is the one the Court wished to implement, then the opposite characterisation of the principle must be seen as weaker in strength and must thus yield to the former one. In that case, we are then faced with a decisional basis for the Court's decision that cannot be sustained. In consequence, the Court's conclusion lacks its major premise.

From the stated above, it can therefore be concluded that the two conceptions of dignity that the Court presented in the Tito Street case are mutually exclusive, making the decision as a whole, internally incoherent.

\section{Concluding remarks}

Symbols carry multiple meanings. This applies for those associated with (former) totalitarian regimes as well. The meanings these symbols convey are often radically different. In the Tito Street case, the Slovenian Constitutional Court concluded that if a symbol can objectively be understood as promoting values incompatible with the values that the constitutional system in effect promotes and protects, then that symbol must be banned - regardless of the fact that some of the meanings of the symbol may be consistent with the constitutional system in force. As we've seen, the idea that a symbol has a single objective meaning is misplaced. This is further evidenced by the approach adopted by the European Court of Human Rights (ECtHR) in the case Vajnai v. Hungary ${ }^{79}$, where the ECtHR emphasised that a totalitarian symbol - in that case a five-pointed red star - also symbolizes certain other ideas and that « only by a careful examination of the context in which the offending words appear that one can draw a meaningful distinction between [...] language which is protected by Article 10 and that which forfeits its right to tolerance in a democratic society ${ }^{80}$. " Moreover, the ECtHR emphasised that a ban on 
certain behaviour can also encompass activities and ideas that are protected by the Convention since "there is no satisfactory way to sever the different meanings of the incriminated symbol ${ }^{81}$. " Though it should be noted that the circumstances of the Vajnai case differed from those in the Tito Street case - namely, in Vajnai the actions of an individual and not of public authorities were contested ${ }^{82}-$, the approach of the ECtHR, emphasising the importance of a comprehensive examination of all relevant contextual circumstances and of the need to accommodate for the different possible interpretations of a disputed symbol, seems more in line with the pluralistic and harmonisational tendencies of modern constitutional democracies. A similar approach, mutatis mutandis, would therefore seem to be more appropriate in the Tito Street case as well.

This brings us to one final criticism of the Court's decision. If we accept the Court's reasoning that, first, the naming of a street has direct legal effect with regard to all who encounter or apprehend it and that, second, due to the axiological and legal weight of the principle of human dignity, any encroachment upon the principle by public authorities is deemed unconstitutional, then the Court's proclamation that only a new naming, i.e. a naming occurring after the establishment of the new democratic constitutional order, is unconstitutional, seems questionable ${ }^{83}$. If mere apprehension of such a name encroaches upon one's dignity - even though, as seen from the BVerfG Abhörurteil case, this notion is indeed hard to sustain -, then the time when such an act of public authorities occurred should not be a determining factor in the Court's decision. Rather, the time of the effects on the individual of apprehending such a name should be relevant in determining whether one's dignity was encroached upon. If public authorities have a negative obligation to refrain from acts that encroach upon one's dignity, surely they also have a positive obligation to prevent such violations from occurring. If, therefore, they must refrain from giving rise to affronts to human dignity by naming streets (and other public facilities) after those who symbolise the former totalitarian regime, surely they have an obligation to remove all existing names making reference to Tito and others who symbolise the former regime. In light of the Court's overall argumentation it is therefore difficult to see how human dignity of individuals is not violated in any and all cases in which the naming of streets or squares after Josip Broz Tito had been made in the past and persists still today. But according to the Court's reasoning, exposure to such symbols does not amount to a violation of the principle of human dignity. Thus, the Court seems to have established a temporally limited scope of the principle of human dignity: the principle which is supposed to be the bedrock of the entire constitutional system. All things considered, such argumentation is unconvincing.

Regardless of these problems, the Tito Street case carries significant precedential value, for it marks the first instance in which the principle of human dignity served as the sole basis for the Court's decision. However, if the criticisms I have presented here are convincing, we can argue that the Court's attempt at defining the principle and determining its role in the constitutional system, is marked by important conceptual lapses and argumentative confusions. This is most evident in the attempt to incorporate the principle of human dignity within the ambit of Article 1 of the Constitution. Due to the fact that it was precisely this argument that served as the basis of the Court's decision, a strong reservation about its overall argumentative quality is in order. 


\section{NOTES}

1. See, for instance, КАтЕв George, Human Dignity, Cambridge (Ma.), The Belknap Press of Harvard University Press, 2011; GRIFFIN James, On Human Rights, New York, Oxford University Press, 2008. 2. See Article 1 of the German Basic Law. On the role of the principle of human dignity in German law see, for instance, ECKERT Joern, "Legal Roots of Human Dignity in German Law ", in The Concept of Human Dignity in Human Rights Discourse, KRETZMER David and KLEIN Eckart (dir.), The Hague, Kluwer Law International, 2002, p. 41-53; KLEIN Eckart, « Human Dignity in German Law », in The Concept of Human Dignity in Human Rights Discourse, op. cit., p. 145-159.

3. One of the controversial questions about human dignity in the human rights discourse is whether it can be protected independently and directly or could that be achieved only through other human rights. Opting for the first possibility raises the further task of establishing that human dignity is in fact substantively different and superior to human rights and not a concept of equal worth. On that matter, see WALDRON Jeremy, «Is Dignity the Foundation of Human Rights? ", in NYU School of Law, Public Law Research Paper No. 12/73, p. 2. Available at: <http:// ssrn.com/abstract=2196074>. Opting for the other possibility, however, raises the question of how the concept of human dignity is added value to the concept of human rights and not just a "facade» behind which the principles of equality and prohibition of discrimination are disguised. On that issue, see POCAR Valerio, «Dignità e non-dignità dell'uomo », in Ragion Pratica $n^{\circ} 1,2012$; MCCRUDDEN Christopher, «Human Dignity and Judicial Interpretation of Human Rights ", in The European Journal of International Law, $\mathrm{n}^{\circ}$ 19/4, 2008, p. 675-678; WALDRON Jeremy, Is Dignity the Foundation of Human Rights?, op. cit., p. 9- .

4. GALLIE Walter Bryce, «Essentially Contested Contepts", in Proceedings of the Aristotelian Society, New Series 56, 1956. On that matter, see for example WALDRON Jeremy, Is Dignity the Foundation of Human Rights?, op. cit., p. 8. Though the same can be said of other important legal and political concepts, such as democracy and the rule of law, it is because of the often stated claim that dignity is superior to these concepts that it is here given special consideration. Cfr. GARZón VALDÉs Ernesto, « Dignity, Human Rights, and Democracy », in Rationality, Markets and Morals n ${ }^{\circ}$ 0, 2009.

5. See, for instance, Article 1, Paragraph 1 of the Constitutional Court Act, Official Gazette of the Republic of Slovenia, $n^{0}$ 64/07 - official consolidated text and 109/12: « The Constitutional Court is the highest body of judicial power for the protection of constitutionality, legality, human rights and fundamental freedoms. "

6. An extensive analysis of the reasons for introducing the concept of human dignity into the constitutions of post-socialist states (with the focus on Hungary) is presented in DUPRÉ Catherine, Importing the Law in Post-Communist transitions. The Hungarian Constitutional Court and the Right to Human Dignity, Oxford, Hart Publishing, 2003. For the explanation of the principle's role in the new Slovenian constitution, see ŠTURM Lovro (dir.), Komentar Ustave Republike Slovenije, Kranj, Fakulteta za državne in evropske študije, 2002 (2011), p. 30-52. I discuss this matter in greater detail in the analysis of the Constitutional Court's decision below.

7. Article 34 of the Constitution states: «Everyone has the right to personal dignity and safety. » Constitution of the Republic of Slovenia, Official Gazette of the Republic of Slovenia, $n^{\circ}$ 33/1991.

8. Prohibition of Incitement to Discrimination and Intolerance and Prohibition of Incitement to Violence and War: «Any incitement to national, racial, religious or other discrimination, and the inflaming of national, racial, religious or other hatred and intolerance are unconstitutional.

Any incitement to violence and war is unconstitutional. » 
9. Arguments of the petitioners are presented in Paragraph 2 of the Court's decision. The text of the decision in English can be accessed at: < http://odlocitve.us-rs.si/usrs/us-odl.nsf/o/ 00E401F6CCF72657C12579EC0036EC05>.

10. For instance, the Basic Constitutional Charter on the Sovereignty and Independence of the Republic of Slovenia and European Parliament resolution of 2 April 2009 on European conscience and totalitarianism.

11. Article 24 of the Constitutional Court Act, regulating this matter, states: (1) Anyone who demonstrates legal interest may lodge a petition that the procedure for the review of the constitutionality or legality of regulations or general acts issued for the exercise of public authority be initiated. (2) Legal interest is deemed to be demonstrated if a regulation or general act issued for the exercise of public authority whose review has been requested by the petitioner directly interferes with his rights, legal interests, or legal position.

12. In the words of the Court, the case raised questions which « refer to human dignity as the fundamental value and legal starting point of Slovenian democracy. These concern the most elementary questions regarding the relation of the state or authorities towards individuals, regarding the position and significance of human beings and humanity in the state, and regarding the fundamental purpose of a free and democratic state in general. » See Paragraph 4 of the decision.

13. See BARDUTZKY Samo, Sprejem zadeve v ustavnosodno presojo, Doctoral Thesis, Constitutional Law, University of Ljubljana, Faculty of Law, 20.2.2013, p. 167. Bardutzky argues that such an understanding of the significance of that sort of rehabilitation of individuals leads to a radically broadened scope of legal interest. Note that in his concurring opinion, judge Zobec (joined by judge Mozetič) argued that anyone, when claiming human dignity had been violated by authoritative acts, should be granted legal interest. For an extensive analysis of the concept of legal interest, see NERAD, Sebastian, « Pravni interes za ustavnosodno presojo zakonov in drugih predpisov ", in Revus $n^{\circ} 4,2005$. Available at: <www.revus.eu>.

14. Paragraph 6 of the Court's decision.

15. For a concise historical account of the principle's inclusion into human rights texts, see MCCRUDDEN Christopher, Human Dignity and Judicial Interpretation of Human Rights, op. cit., p. 664675. The concept of human dignity, understood as the basis of human rights, was first introduced into declarations of rights in 1948 with the UN Universal Declaration of Human Rights. See, for instance, DICKE Klaus, «The Founding Function of Human Dignity in the Universal Declaration of Human Rights » in KRETZMER David and KLEIN Eckart (dir.), The Concept of Human Dignity in Human Rights Discourse, op. cit, p. 111-120.

16. Par. 6 of the Court's decision.

17. Article III, Paragraph 1 of the Basic Constitutional Charter states: « The Republic of Slovenia guarantees the protection of human rights and fundamental freedoms to all persons in the territory of the Republic of Slovenia irrespective of their national origin, without any discrimination whatsoever, in accordance with the Constitution of the Republic of Slovenia and the treaties in force."

18. Par. 8 of the Court's decision.

19. Ibid.

20. See Par. 9 of the Court's decision. Among these provisions the Court lists Article 14 (prohibition of discrimination, Article 17 (inviolability of human life), Article 18 (prohibition of torture), Article 19 (protection of personal liberty), Article 21 (protection of human personality and dignity in legal proceedings), Article 29 (legal guarantees in criminal proceedings), Article 34 (the right to personal dignity and safety), Article 39 (freedom of expression) and Article 41 (freedom of conscience).

21. See Par. 10 of the Court's decision. It should be noted at this point that the Court did not examine the constitutionality of the ordinance in light of Articles 34 and 63 of the Constitution 
on which the petitioners based their petition. Article 30 of the Constitutional Court Act states that the Court, when deciding on the constitutionality and legality of a regulation or general act issued for the exercise of public authority, is not bound by the proposal of a request or petition.

22. Par. 10 of the Court's decision.

23. Ibid.

24. See Par. 11 of the Court's decision.

25. Par. 14 of the Court's decision.

26. Ibid. The Court reached this conclusion due to the fact that «[o]fficial acts of state and municipal authorities which have a symbolic significance can namely not be considered to be equivalent to a situation in which individuals or groups express different opinions and convictions; their right to express opinions and standpoints that can even be contrary to the fundamental constitutional values is within the framework of a free and pluralistic society supported in the constitutional provisions on freedom of conscience and freedom of expression. However, when public authorities express certain values it is not a matter of freedom of expression, as it is in the nature of this human right that only individuals and associations are entitled to it, and not the authorities. »

27. Par. 15 of the Court's decision.

28. Ibid.

29. Ibid.

30. Ibid.

31. Par. 16 of the Court's decision.

32. The Italian constitutional conception of human dignity, for instance, differs substantially from the German model. Cfr. BECCHI Paolo, «La dignità umana nel Grundgesetz e nella costituzione italiana ", in Ragion Pratica ${ }^{\circ} 1,2012$.

33. See above all KANT Immanuel, The Groundwork for the Metaphysics of Morals, New Haven, London, Yale University Press, 2002 [1785]. More on the Kantian background of the Dignity clause in the German Basic Law, see ROSEN Michael, Dignity. Its History and Meaning, Cambridge (Ma.), Harvard University Press, 2011, especially p. 80-90.

34. ROSEN Michael, Dignity. Its History and Meaning, op. cit., p. 115. The first paragraph of Article 1 of the German Basic Law states: « Human dignity shall be inviolable. To respect and protect it shall be the duty of all state authority. » To be sure, in Kant's philosophy humans do not have dignity simply because they exist - to have dignity one must before that have morality. It is morality, argues Kant, and humanity insofar as it is capable of morality, that alone has dignity. See ECKERT Joern, Legal Roots of Human Dignity in German Law, op. cit., p. 46.

35. WALTER Christian, « Human dignity in German constitutional law », in The principle of respect for human dignity, European Commission for Democracy Through Law, Montpellier, Proceedings of the UniDem Seminar, 1998. Available at: <http://www.venice.coe.int/webforms/documents/CDLSTD(1998)026-e.aspx>.

36. Ibid.

37. Ibid.

38. More on that see BECCHI Paolo, La dignità umana nel Grundgesetz e nella costituzione italiana, op. cit.

39. KLEIN Eckart, Human Dignity in German Law, op. cit., p. 146-147.

40. Ibid., p. 146-149.

41. Ibid., p. 149.

42. Ibid., p. 148.

43. Ibid., p. 149. Similarly, ROSEN Michael, Dignity. Its History and Meaning, op. cit., p. 107, pointing to two important and widely known cases (the Daschener case - known also as the Gäfgen case, and 
the Air Safety Law case), shows that this is indeed the view of German court, despite the inherent complications such a stringent position brings.

44. RoSEn Michael, Dignity. Its History and Meaning, op. cit., p. 115.

45. Ibid., p. 115. Emphasis added. Rosen identifies four conceptions of dignity: dignity as rank or status, dignity as intrinsic value, dignity as measured and self-possessed behaviour and the idea that people ought to be treated with dignity. See Ibid., p. 114. Similarly Waldron argues that law protects dignity (as status) both by way of specific norms (rights provisions) as well as through its very form and structure. See WALDRON Jeremy, " How Law Protects Dignity ", in The Cambridge Law Journal $\mathrm{n}^{\circ} 1,2012$, p. 200-222.

46. BVerfGE, 30, I, in ROSEN Michael, Dignity. Its History and Meaning, op. cit., p. 115-116.

47. Full text of the Charter can be accessed here: < http://unpan1.un.org/intradoc/groups/ public/documents/UNTC/UNPAN014895.pdf>

48. See ŠTURM Lovro, Komentar Ustave Republike Slovenije, op. cit., p. 32 and Court's case U-I-168/97 from $3^{\text {rd }}$ July 1997.

49. Decision U-I-158/94, $9^{\text {th }}$ March 1994.

50. See more in šTURM Lovro, Komentar Ustave Republike Slovenije, op. cit., 2002, p. 236-238, and the 2011 supplement, p. 269-273.

51. Up-183/97, from $10^{\text {th }}$ July 1997 (Par. 24).

52. See case U-I-66/93, from 2nd December 1993.

53. U-I-25/95, from $27^{\text {th }}$ November 1997.

54. U-I-226/95, from $8^{\text {th }}$ July 1999.

55. U-I-158/94, from $9^{\text {th }}$ March 1995.

56. U-I-107/96, from $5^{\text {th }}$ December 1996 (Par. 35).

57. U-I-69/92, from $10^{\text {th }}$ December 1992.

58. MCCRUDDEN Christopher, Human Dignity and Judicial Interpretation of Human Rights, op. cit., p. 706.

59. Ibid.

60. Ibid., p. 707.

61. Ibid. A similar warning is brandished by Feldman, saying that « [a]llowing a right to dignity in a justiciable constitution invites judges to give it a content reflecting their preferred values. » See FELDMAN David, « Human dignity as a legal value: Part 1 », in Public Law, 1999, p. 697.

62. We should be mindful to distinguish (at least) two different understandings of the term " objective meaning »: McCrudden employs the term to distinguish two possible points of view in interpreting (understanding) the concept of human dignity, namely the victim's and the judge's; the second understanding of objectivity is that according to which words have an objective meaning, i.e. they can be interpreted (understood) only in one, correct, way. However, Guastini argues that there is no such thing as an objective meaning of normative texts: each is at least potentially equivocal. See GUASTINI Riccardo, L'interpretazione dei documenti normativi, Milano, Giuffrè, 2004, p. 260.

63. See Paragraph 8 of the Court's decision. Emphasis added.

64. Schachter has similarly emphasised that the lack of « reasonably clear general idea of [dignity's] meaning" amounts to a difficulty in drawing "specific implications for relevant conduct. " See WALDRON Jeremy, Is Dignity the Foundation of Human Rights?, op. cit., p. 7, quoting SCHACHTER Oscar, « Human Dignity as a Normative Concept», in American Journal of International Law 77 (1983) 848.

65. Paragraph 12 of the Court's decision.

66. Ibid.

67. In her concurring opinion, judge Korpič Horvat argues that the Court in these two paragraphs did not respect its own declaration that its reasoning will be based on a »constitutional review 
and not on an explanation and evaluation of the facts and circumstances of the relevant historical period."

68. ŠTURM Lovro, «Ustavnosodna presoja o razmejitvi totalitarnega sistema in svobodne demokratične družbe temelječe na človekovem dostojanstvu», in Pomen ustavnosti in ustavna demokracija, KAUčrč Igor (dir.), Ljubljana, Ustavno sodišče Republike Slovenije, 2012, p. 81.

69. Ibid.

70. AVBELJ Matej, «Zgodovinska odločitev Ustavnega sodišča », in Pravna praksa, nº 39/40, 2011, p. 18. Translation by M.Ž.

71. Ibid., p. 19.

72. BERTEA Stefano, "The Argument from Coherence ", in The IVR Encyclopaedia of Jurisprudence, Legal Theory and Philosophy of Law, 2009. Available at: < http://ivr-enc.info/index.php? title=The_Argument_from_Coherence>.

73. See, for instance, WEBER Max, "Three types of legitimate rule", in Berkley Publications in Society and Institutions, $\mathrm{n}^{\circ} 4$ (1), 1958. In Slovenian transl.: « Trije čisti tipi legitimne oblasti », in Družboslovne razprave, $\mathrm{n}^{\circ}$ 9, 1990.

74. BERTEA Stefano, The Argument from Coherence, op. cit.

75. Ibid.; DICKSON Julie, "Interpretation and Coherence in Legal Reasoning " in The Standard Encyclopedia of Philosophy (Spring 2010 Edition), zALTA Edward (dir.). Available at: <http:// plato.stanford.edu/archives/spr2010/entries/legal-reas-interpret/>.

76. BERTEA Stefano, The Argument from Coherence, op. cit.

77. Theorists differ as to the level of importance coherence should be attributed in justifying a judicial decision. While some claim that it is a necessary (and even a sufficient) condition, others argue that it is only a desired feature of a decision. For more on that, see DICKSON Julie, Interpretation and Coherence in Legal Reasoning, op. cit.

78. The Court has on numerous occasions determined that fact. See Court's decision U-I-111/04, from $8^{\text {th }}$ July 2004, Par. 26: « In the Republic of Slovenia, a so-called constitutional democracy was established, the essence of which is that the values protected by the Constitution, including, in particular, human rights and freedoms (the preamble to the Constitution), can prevail over the democratically adopted decisions of the majority. " See also HASSEMER, Winfried, "Ustavna demokracija ", in Pravnik, $n^{\circ}$ 4/5, 2003.

79. See Vajnai v. Hungary [2008] ECHR 33629/06 (8 July 2008).

80. See Paragraph 53 of the Vajnai decision. Emphasis added.

81. Ibid., Par. 54.

82. The Slovenian Constitutional Court had also made a distinction between these two types of cases. See above, footnote 26.

83. See Paragraph 18 of the Tito Street decision.

\section{ABSTRACTS}

The article examines the Slovenian Constitutional Court's understanding of the principle of human dignity. It focuses on a recent case of that Court in which human dignity was for the first time employed as an independent principle of adjudication. The case concerned an alleged violation of the principle of human dignity by an act of naming a street after the former Yugoslav president Josip Broz Tito. After a detailed examination of the decision, the article explores the 
Court's application of the principle prior to this verdict. Finally, a two-fold criticism of the Court's reasoning in the Tito Street case is presented. The central objection argues that different characterisations of the principle of human dignity and of its role in the constitutional system contradict each other, making the final decision's coherence questionable.

L'article se propose d'étudier la façon dont la Cour constitutionnelle de Slovénie comprend le principe de dignité. Pour ce faire, il prend pour exemple une récente décision de la Cour dans laquelle la dignité humaine a été employée pour la première fois comme fondement juridique indépendant du contrôle de constitutionnalité. La décision portait sur l'allégation de la violation du principe de dignité humaine en ce qu'il devait être donné à une rue le nom de l'ex-Président de la Yougoslavie "Josip Broz Tito". Après un examen détaillé des circonstances de la décision, l'article examine la façon dont la Cour applique le principe. Il propose pour finir deux types de critiques qui peuvent être adressées au raisonnement de la Cour dans cette décision Tito Street. Les objections centrales reposent sur les différentes approches du principe de dignité proposées par la Cour, sur la fonction contradictoire du principe au sein du système constitutionnel et sur la cohérence de la décision adoptée.

El artículo propone estudiar la manera a través de la cual el Tribunal constitucional de Eslovenia entiende al principio de dignidad. Para tal fin, se toma como ejemplo a una decisión recientemente emitida por el Tribunal en la cual, la dignidad humana es empleada por primera vez como fundamento jurídico independiente del control de constitucionalidad. La decisión trata sobre el alegato de violación del principio de dignidad humana por cuanto se debía dar a una calle el nombre del ex presidente de Yugoslavia "Josip Broz Tito". Luego de un examen detallado sobre las circunstancias de la decisión, el artículo examina la forma a través de la cual el Tribunal aplica dicho principio. Se proponen, para terminar, dos tipos de crítica que pueden ser dirigidas contra el razonamiento del Tribunal en esta decisión Tito Street. Las objeciones centrales ce basan en los diferentes enfoques del principio de dignidad que el Tribunal propuso, en la función contradictoria de dicho principio en el seno del sistema constitucional y en la coherencia de la decisión adoptada.

\section{INDEX}

Mots-clés: principe de dignité humaine, droits de l'homme, symboles (totalitaires), contrôle de constitutionnalité, Cour constitutionnelle de la République Slovène

Keywords: principle of human dignity, human rights, (totalitarian) symbols, constitutional adjudication, Constitutional Court of the Republic of Slovenia.

Palabras claves: principio de dignidad, derechos humanos, control de constitucionalidad, Tribunal constitucional de Eslovenia

\section{AUTHOR}

\section{MATIJA ŽGUR}

Matija Žgur a étudié la théorie du droit à l'Université de Gênes. Il est doctorant à l'Université de Palerme. Il travaille auprès du Constitutional Law Institute de Ljubljana.

Master in Global Rule of Law and Constitutional Democracy (University of Genoa) matija.zgur@gmail.com 